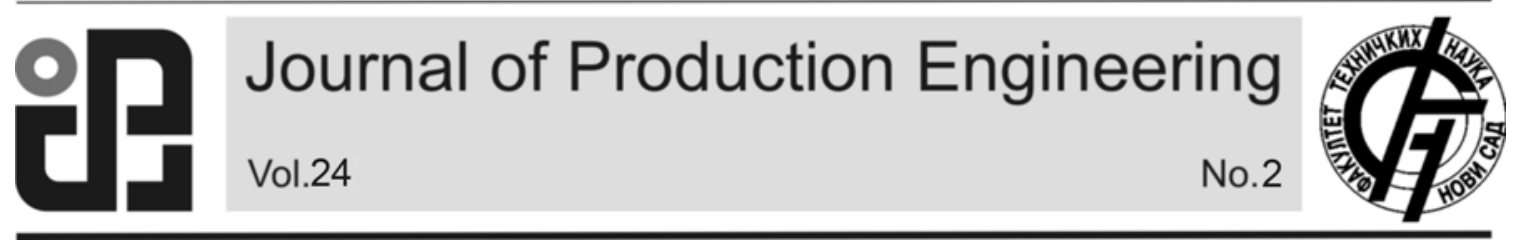

JPE (2021) Vol.24 (2)

Bodzás, S., Békési, Zs., Kertész, J., Szorcsik, T.

Original Scientific Paper

\title{
TOOTH CONTACT ANALYSIS OF A DESIGNED PLANETARY GEAR DRIVE FOR THE VEHICLE INDUSTRY
}

Abstract: A planetary gear drive consists of a sun gear, planet pinions and an internal gear. We designed a complex gear system which is usable in the field of the vehicle industry into the automatized robots. The system was designed by GearTeq software which is connected with the SolidWorks designer software. After the assembly and the motion simulations tooth contact analysis (TCA) was made to analyse the normal stresses and the normal deformations on the connecting surface of the planet pinions and the internal gear by different load moments.

Key words: Planetary gear drive, CAD, TCA, normal stress, normal deformation, analysis.

Analiza kontakta zuba projektovanog planetarnog zupčanika za industriju vozila. Pogon planetarnog zupčanika sastoji se od sunčanog zupčanika, planetarnih zupčanika i unutrašnjeg zupčanika. U automatizovane robote dizajnirali smo složen sistem zupčanika koji je upotrebljiv u oblasti industrije vozila. Sistem je dizajnirao GearTek softver koji je povezan sa SolidVorks dizajnerskim softverom. Nakon montaže i simulacije kretanja izvršena je analiza kontakta zuba (TCA) za analizu normalnih napona i normalnih deformacija na spojnoj površini planetarnih zupčanika i unutrašnjeg zupčanika po različitim momentima opterećenja.

Ključne reči: Planetarni zupčanik, CAD, TCA, normalno naprezanje, normalna deformacija, analiza.

\section{INTRODUCTION}

The planetary gear drives have two gear systems. The axis of the first system is fixed where the planet gears can rotate around it. The planet carrier can also rotate around it. The axes of the second system are assembled into the planet carrier and their teeth can connect with the first system. These planet pinions can rotate around their axes and the fixed axes of the first system [1, 3-5, 7, 9]. The overall mechanism show a similar motion as the Earth moves around the Sun (two rotation motions around two axes). The sun gear is the central gear which has a fix axes. The planet gears can do two rotation motions parallely. The internal gear is fixed. The planet gears are rotated by the sun gear and they are connected with the internal gear (Figure 1) [1, $3-5,7,9]$.
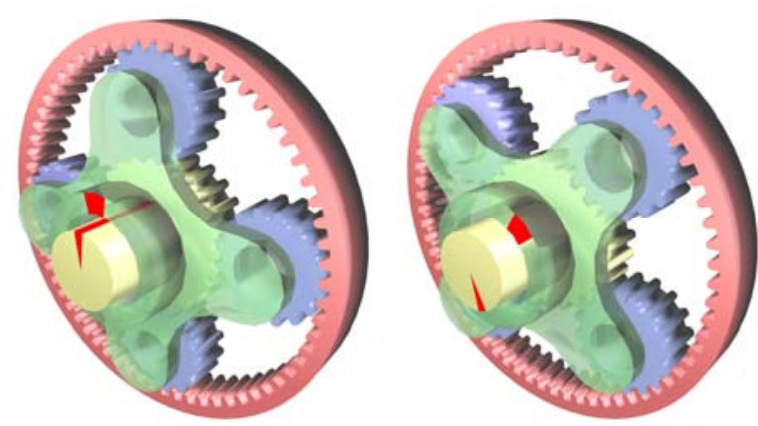

Fig. 1. The theorem of the planetary gear drive [1]

Considering the function of the gear system the sun gear can be pinion or gear. The planet pinions can also be pinions or gears. The yellow and green axes are not connected. The connection between them depends on the gear ratio (Figure 1) [1, 3-5, 7, 9].

\section{THE GEOMETRIC DESIGN OF A GEAR SYSTEM}

The geometric design process [3, 6-9] was created by the GearTeq software [2] with which different type of gear pairs can be designed (Figure 2). After knowing of the output geometric parameters the CAD models can be created by SolidWorks software (Figure 3).

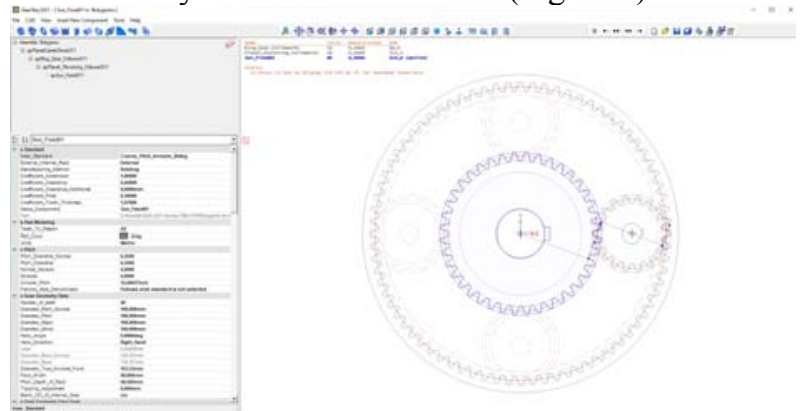

Fig. 2. Geometric design by GearTeq software

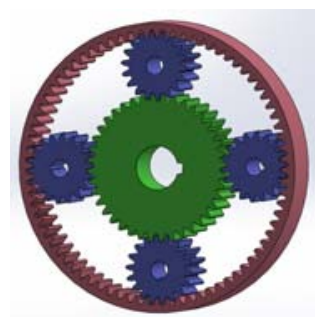

Fig. 3. The geometric establishment of the designed planetary gear drive

The calculated geometric parameters can be seen on Table 1, 2 and 3. After the assembly and the motion simulations the TCA can be determined. 


\begin{tabular}{|c|c|c|c|}
\hline SYMBOL & VALUE & UNIT & TERM \\
\hline & Coarse_Pitch_Involute_20de & & Standard \\
\hline Pdn & 6,3 & & Normal Diametral Pitch \\
\hline \multirow[t]{2}{*}{$\mathrm{Pd}$} & 6,3 & & Diametral Pitch \\
\hline & & & Normal Modular Pitch \\
\hline $\mathrm{m}$ & & 4 & Modular Pitch \\
\hline$\emptyset n$ & & 200 deg & Normal Pressure Angle \\
\hline \multirow[t]{4}{*}{$\varnothing$} & & odeg & Pressure Angle \\
\hline & & odeg & Helix Angle \\
\hline & & & \\
\hline & Gear Data & & Ring_Gear_Follower01 \\
\hline $\mathrm{Np}$ & & 6 & Number of Teeth \\
\hline $\mathrm{Dp}$ & 30 & $4 \mathrm{~mm}$ & Pitch Diameter \\
\hline Dpn & 30 & $4 \mathrm{~mm}$ & Pitch Diameter, Normal \\
\hline do & 31 & $14 \mathrm{~mm}$ & Major Diameter \\
\hline $\mathrm{dr}$ & $2 \mathrm{~s}$ & $6 \mathrm{~mm}$ & Minor Diameter \\
\hline $\mathrm{a}$ & & $4 \mathrm{~mm}$ & Addendum \\
\hline $\mathrm{b}$ & & $5 \sqrt{\mathrm{mm}}$ & Dedendum \\
\hline \multirow[t]{2}{*}{$\mathrm{x}$} & & 0 & Addendum Modification Coefficient \\
\hline & & $\mathrm{mm}$ & Addendum Modification \\
\hline$d b$ & 285,66 & $7 \mathrm{~mm}$ & Base Diameter \\
\hline $\mathrm{dbn}$ & 285,66 & $7 \mathrm{~mm}$ & Base Diameter, Normal \\
\hline TIF & $312,3]$ & $7 \mathrm{~mm}$ & True Involute Form Diameter \\
\hline ht & & $9 \mathrm{~mm}$ & Whole Depth \\
\hline$p$ & 12,56 & $56 \mathrm{~mm}$ & Circular Pitch \\
\hline \multirow[t]{2}{*}{$\mathrm{pn}$} & 12,56 & $6 \mathrm{~mm}$ & Circular Pitch, Normal \\
\hline & & $2 \mathrm{~mm}$ & Fillet Radius \\
\hline \multirow[t]{3}{*}{$B$} & & $4 \mathrm{~mm}$ & Backlash \\
\hline & 6,68 & $2 \mathrm{~mm}$ & Space Width \\
\hline & 6,835 & $2 \mathrm{~mm}$ & Space Width Maximum \\
\hline t & 5,883 & $2 \mathrm{~mm}$ & Tooth Thickness \\
\hline $\operatorname{tn}$ & 5,88 & $2 \mathrm{~mm}$ & Tooth Thickness, Normal \\
\hline 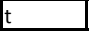 & 5,73 & $2 \mathrm{~mm}$ & Tooth Thickness Minimum \\
\hline \multirow[t]{7}{*}{$\mathrm{F}$} & & 50 & Face Width \\
\hline & & & Chordal Tooth Thickness \\
\hline & 0,8 & & Chordal Tooth Height \\
\hline & 312,3 & & Chordal Tooth Reference Circle \\
\hline & 2,63 & & Chordal Tooth Thickness \\
\hline & 2,48 & & Chordal Tooth Thickness Minimum \\
\hline & & & Size Between Pins \\
\hline $\mathrm{dw}$ & 5,2 & $5 \sqrt[\mathrm{mm}]{\mathrm{m}}$ & Pin Diameter \\
\hline \multirow[t]{3}{*}{$\mathrm{M}$} & 302,1 & $11 \mathrm{~mm}$ & Measurement Between Pins \\
\hline & 301,7 & $3 \mathrm{~mm}$ & Measurement Between Pins-Minimum \\
\hline & & & Span Over Teeth \\
\hline \multirow[t]{18}{*}{$\mathrm{k}$} & & & Number of Teeth to Span Over \\
\hline & $-1,2$ & $1 \mathrm{~mm}$ & Span Measurement \\
\hline & $-1,1$ & $28 \mathrm{~mm}$ & Span Measurement Minimum \\
\hline & & & Master Gear Test \\
\hline & & & Master Pitch Diameter \\
\hline & & $0 \mathrm{~mm}$ & Test Radius (Max. Act.) \\
\hline & & $\mathrm{mm}$ & Test Radius (Min. Act.) \\
\hline & AGMA-Q7 & & AGMA Quality Class \\
\hline & 0,15 & $24 \mathrm{~mm}$ & Max Runout \\
\hline & 0,03 & $31 \mathrm{~mm}$ & Pitch Variation \\
\hline & 0,05 & $89 \mathrm{~mm}$ & Profile Tolerance \\
\hline & & $\mathrm{mm}$ & Tooth Alignment Tolerance \\
\hline & 0,058 & $12 \mathrm{~mm}$ & Tooth to Tooth Composite Tolerance \\
\hline & 0,213 & $36 \mathrm{~mm}$ & Total Composite Tolerance \\
\hline & 0,1 & $2 \sqrt{\mathrm{mm}}$ & Tooth Thickness Tolerance \\
\hline & & $09 \mathrm{~mm}$ & Hob Protuberance \\
\hline & 26, & 14 deg & Roll Angle at Major Diameter \\
\hline & 25, & 32 deg & Roll Angle at TIF Diameter \\
\hline
\end{tabular}

Table 1. Geometric parameters of the internal gear

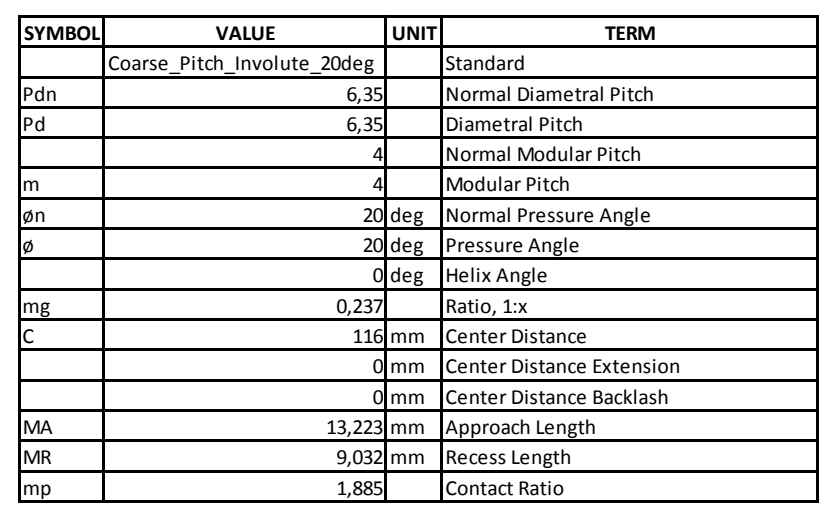

\begin{tabular}{|c|c|c|c|}
\hline & Not Hunting & & Hunting Determination \\
\hline & 4560 & & Hunting Mesh Cycle \\
\hline & 1,2 & & Hunting Common Factors \\
\hline & $6.7 \mathrm{cpm}$ & & Hunting Tooth Frequency \\
\hline & 253,3 & & Pinion RPM \\
\hline & Gear Data & & Ring Gear Follower01 \\
\hline $\mathrm{Np}$ & 76 & 6 & Number of Teeth \\
\hline $\mathrm{Dp}$ & & $4 \mathrm{~mm}$ & Pitch Diameter \\
\hline $\mathrm{Dpn}$ & 304 & $4 \mathrm{~mm}$ & Pitch Diameter, Normal \\
\hline do & 314 & $4 \mathrm{~mm}$ & Major Diameter \\
\hline $\mathrm{dr}$ & 296 & $6 \mathrm{~mm}$ & Minor Diameter \\
\hline a & & $4 \mid \mathrm{mm}$ & Addendum \\
\hline $\mathrm{b}$ & & $5 \mathrm{~mm}$ & Dedendum \\
\hline $\mathrm{x}$ & 0 & 0 & Addendum Modification Coefficient \\
\hline & & $0 \mathrm{~mm}$ & Addendum Modification \\
\hline$d b$ & 285,667 & $7 \mathrm{~mm}$ & Base Diameter \\
\hline $\mathrm{dbn}$ & 285,667 & $7 \mathrm{~mm}$ & Base Diameter, Normal \\
\hline TIF & 312,317 & $7 \mathrm{~mm}$ & True Involute Form Diameter \\
\hline ht & & $9 \mathrm{~mm}$ & Whole Depth \\
\hline $\mathrm{p}$ & 12,566 & $6 \mathrm{~mm}$ & Circular Pitch \\
\hline $\mathrm{pn}$ & 12,566 & $6 \mathrm{~mm}$ & Circular Pitch, Normal \\
\hline & 1,2 & $2 \mathrm{~mm}$ & Fillet Radius \\
\hline$B$ & 0,4 & $4 \mathrm{~mm}$ & Backlash \\
\hline & 6,6832 & $2 \mathrm{~mm}$ & Space Width \\
\hline & 6,8352 & $2 \mathrm{~mm}$ & Space Width Maximum \\
\hline$t$ & 5,8832 & $2 \mathrm{~mm}$ & Tooth Thickness \\
\hline tn & 5,8832 & $2 \mathrm{~mm}$ & Tooth Thickness, Normal \\
\hline & 5,7312 & $2 \mid \mathrm{mm}$ & Tooth Thickness Minimum \\
\hline $\mathrm{F}$ & 50 & $\mathrm{~mm}$ & Face Width \\
\hline & & & Chordal Tooth Thickness \\
\hline & 0,869 & & \begin{tabular}{|l} 
Chordal Tooth Height \\
\end{tabular} \\
\hline & 312,317 & & \begin{tabular}{|l} 
Chordal Tooth Reference Circle \\
\end{tabular} \\
\hline & 2,6396 & & Chordal Tooth Thickness \\
\hline & 2,4835 & & Chordal Tooth Thickness Minimum \\
\hline & & & Size Between Pins \\
\hline $\mathrm{dw}$ & 5,225 & $5 \mathrm{~mm}$ & Pin Diameter \\
\hline $\mathrm{M}$ & 302,141 & $1 \mathrm{~mm}$ & Measurement Between Pins \\
\hline & 301,753 & $3 \mathrm{~mm}$ & Measurement Between Pins-Minimum \\
\hline & & & Span Over Teeth \\
\hline k & 0 & of & Number of Teeth to Span Over \\
\hline & $-1,271$ & $1 \mathrm{~mm}$ & \begin{tabular}{|l} 
Span Measurement \\
\end{tabular} \\
\hline & $-1,128$ & $8 \mathrm{~mm}$ & Span Measurement Minimum \\
\hline & & & Master Gear Test \\
\hline & 0 & & Master Pitch Diameter \\
\hline & & $\mathrm{mm}$ & Test Radius (Max. Act.) \\
\hline & & $\mathrm{mm}$ & \begin{tabular}{|l} 
Test Radius (Min. Act.) \\
\end{tabular} \\
\hline & AGMA-Q7 & & AGMA Quality Class \\
\hline & 0,1524 & $4 \mathrm{~mm}$ & Max Runout \\
\hline & 0,0381 & $1 \mathrm{~mm}$ & Pitch Variation \\
\hline & 0,0508 & $8 \mathrm{~mm}$ & Profile Tolerance \\
\hline & & $0 \mathrm{~mm}$ & Tooth Alignment Tolerance \\
\hline & 0,05842 & $2 \mathrm{~mm}$ & Tooth to Tooth Composite Tolerance \\
\hline & 0,21336 & $6 \mathrm{~mm}$ & Total Composite Tolerance \\
\hline & 0,152 & $2 \mathrm{~mm}$ & Tooth Thickness Tolerance \\
\hline & & $0 \mathrm{~mm}$ & Hob Protuberance \\
\hline & 26,14 & 4 deg & Roll Angle at Major Diameter \\
\hline & 25,32 & $2 \mathrm{deg}$ & Roll Angle at TIF Diameter \\
\hline & & & \\
\hline & Pinion Data & & Planet_Revolving_Follower01 \\
\hline $\mathrm{Np}$ & 18 & & Number of Teeth \\
\hline $\mathrm{Dp}$ & & $2 \mathrm{~mm}$ & Pitch Diameter \\
\hline Dpn & & $2 \mathrm{~mm}$ & Pitch Diameter, Normal \\
\hline do & & $\mathrm{mm}$ & Major Diameter \\
\hline $\mathrm{dr}$ & 62 & $2 \mathrm{~mm}$ & Minor Diameter \\
\hline a & & $4 \mathrm{~mm}$ & Addendum \\
\hline $\mathrm{b}$ & & $5 \mathrm{~mm}$ & Dedendum \\
\hline $\mathrm{x}$ & 0 & 0 & Addendum Modification Coefficient \\
\hline & & $0 \mathrm{~mm}$ & Addendum Modification \\
\hline $\mathrm{db}$ & 67,658 & $8 \mathrm{~mm}$ & Base Diameter \\
\hline $\mathrm{dbn}$ & 67,658 & $8 \mathrm{~mm}$ & Base Diameter, Normal \\
\hline TIF & 67,658 & $8 \mathrm{~mm}$ & True Involute Form Diameter \\
\hline ht & & $9 \mathrm{~mm}$ & Whole Depth \\
\hline $\mathrm{p}$ & 12,566 & $6 \mathrm{~mm}$ & Circular Pitch \\
\hline $\mathrm{pn}$ & 12,566 & $6 \mathrm{~mm}$ & Circular Pitch, Normal \\
\hline & & $2 \mathrm{~mm}$ & Fillet Radius \\
\hline$B$ & 0,4 & $4 \mathrm{~mm}$ & Backlash \\
\hline$t$ & 5,8832 & $2 \mathrm{~mm}$ & Tooth Thickness \\
\hline tn & 5,8832 & $2 \mathrm{~mm}$ & Tooth Thickness, Normal \\
\hline $\mathrm{F}$ & & $0 \mathrm{~mm}$ & Face Width \\
\hline & & & Chordal Tooth Thickness \\
\hline & 6,299 & & Chordal Tooth Height \\
\hline & 67,658 & & \begin{tabular}{|l} 
Chordal Tooth Reference Circle \\
\end{tabular} \\
\hline & 6,5266 & & Chordal Tooth Thickness \\
\hline & 6,3844 & & Chordal Tooth Thickness Minimum \\
\hline & & & Size Over Pins \\
\hline$d w$ & 6,967 & $7 \mathrm{~mm}$ & Pin Diameter \\
\hline
\end{tabular}




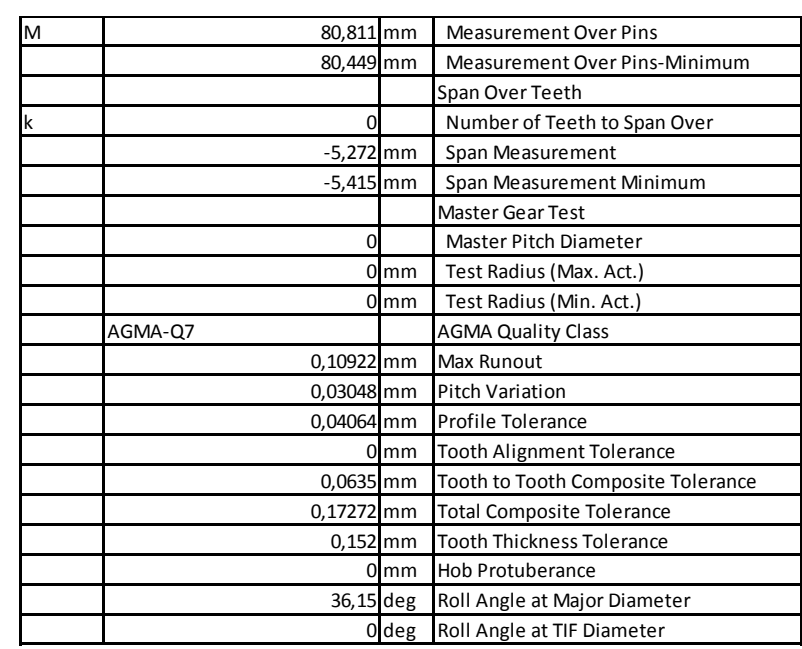

Table 2. Geometric parameters of the planet pinions

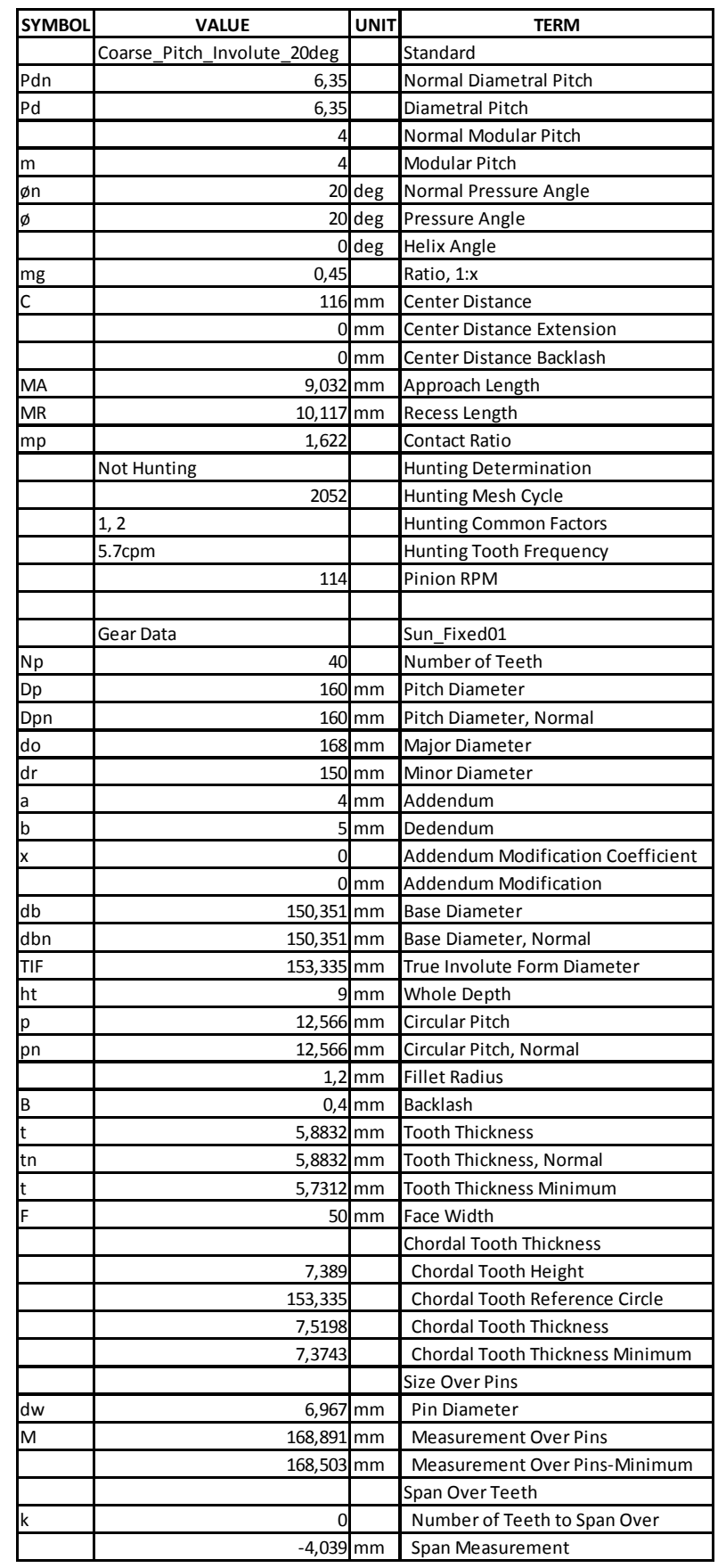

\begin{tabular}{|c|c|c|c|c|}
\hline & & $-4,182$ & $\mathrm{~mm}$ & Span Measurement Minimum \\
\hline & & & & Master Gear Test \\
\hline & & 0 & & Master Pitch Diameter \\
\hline & & & $\mathrm{mm}$ & Test Radius (Max. Act.) \\
\hline & & & $\mathrm{mm}$ & Test Radius (Min. Act.) \\
\hline & AGMA-Q7 & & & AGMA Quality Class \\
\hline & & 0,13208 & $\mathrm{~mm}$ & Max Runout \\
\hline & & 0,03556 & $\mathrm{~mm}$ & Pitch Variation \\
\hline & & 0,04572 & $\mathrm{~mm}$ & Profile Tolerance \\
\hline & & & $\mathrm{mm}$ & Tooth Alignment Tolerance \\
\hline & & 0,05842 & $\mathrm{~mm}$ & Tooth to Tooth Composite Tolerance \\
\hline & & 0,18796 & $\mathrm{~mm}$ & Total Composite Tolerance \\
\hline & & 0,152 & $\mathrm{~mm}$ & Tooth Thickness Tolerance \\
\hline & & & $\mathrm{mm}$ & Hob Protuberance \\
\hline & & 28,56 & deg & Roll Angle at Major Diameter \\
\hline & & 11,47 & deg & Roll Angle at TIF Diameter \\
\hline & & & & \\
\hline & Pinion Data & & & Planet_Revolving_Follower01 \\
\hline $\mathrm{Np}$ & & 18 & & Number of Teeth \\
\hline Dp & & 72 & $\mathrm{~mm}$ & Pitch Diameter \\
\hline $\mathrm{Dpn}$ & & 72 & $\mathrm{~mm}$ & Pitch Diameter, Normal \\
\hline do & & 80 & $\mathrm{~mm}$ & Major Diameter \\
\hline $\mathrm{dr}$ & & 62 & $\mathrm{~mm}$ & Minor Diameter \\
\hline a & & & $\mathrm{mm}$ & Addendum \\
\hline$\underline{b}$ & & 5 & $\mathrm{~mm}$ & Dedendum \\
\hline \multirow[t]{2}{*}{$\mathrm{x}$} & & I & & Addendum Modification Coefficient \\
\hline & & & $\mathrm{mm}$ & Addendum Modification \\
\hline $\mathrm{db}$ & & 67,658 & $\mathrm{~mm}$ & Base Diameter \\
\hline $\mathrm{dbn}$ & & 67,658 & $\mathrm{~mm}$ & Base Diameter, Normal \\
\hline TIF & & 67,658 & $\mathrm{~mm}$ & True Involute Form Diameter \\
\hline ht & & & $\mathrm{mm}$ & Whole Depth \\
\hline p & & 12,566 & $\mathrm{~mm}$ & Circular Pitch \\
\hline \multirow[t]{2}{*}{$\mathrm{pn}$} & & 12,566 & $\mathrm{~mm}$ & Circular Pitch, Normal \\
\hline & & 1,2 & $\mathrm{~mm}$ & Fillet Radius \\
\hline$B$ & & 0,4 & $\mathrm{~mm}$ & Backlash \\
\hline $\mathrm{t}$ & & 5,8832 & $\mathrm{~mm}$ & Tooth Thickness \\
\hline tn & & 5,8832 & $\mathrm{~mm}$ & Tooth Thickness, Normal \\
\hline \multirow[t]{7}{*}{$\Gamma$} & & 50 & $\mathrm{~mm}$ & Face Width \\
\hline & & & & Chordal Tooth Thickness \\
\hline & & 6,299 & & Chordal Tooth Height \\
\hline & & 67,658 & & Chordal Tooth Reference Circle \\
\hline & & 6,5266 & & Chordal Tooth Thickness \\
\hline & & 6,3844 & & Chordal Tooth Thickness Minimum \\
\hline & & & & Size Over Pins \\
\hline $\mathrm{dw}$ & & 6,967 & $\mathrm{~mm}$ & Pin Diameter \\
\hline \multirow[t]{3}{*}{$\mathrm{M}$} & & 80,811 & $\mathrm{~mm}$ & Measurement Over Pins \\
\hline & & 80,449 & $\mathrm{~mm}$ & Measurement Over Pins-Minimum \\
\hline & & & & Span Over Teeth \\
\hline \multirow[t]{18}{*}{ k } & & 0 & & Number of Teeth to Span Over \\
\hline & & $-5,272$ & $\mathrm{~mm}$ & Span Measurement \\
\hline & & $-5,415$ & $\mathrm{~mm}$ & Span Measurement Minimum \\
\hline & & & & Master Gear Test \\
\hline & & 0 & & Master Pitch Diameter \\
\hline & & & $\mathrm{mm}$ & Test Radius (Max. Act.) \\
\hline & & & $\mathrm{mm}$ & Test Radius (Min. Act.) \\
\hline & AGMA-Q7 & & & AGMA Quality Class \\
\hline & & 0,10922 & $\mathrm{~mm}$ & Max Runout \\
\hline & & 0,03048 & $\mathrm{~mm}$ & Pitch Variation \\
\hline & & 0,04064 & $\mathrm{~mm}$ & Profile Tolerance \\
\hline & & & $\mathrm{mm}$ & Tooth Alignment Tolerance \\
\hline & & 0,0635 & $\mathrm{~mm}$ & Tooth to Tooth Composite Tolerance \\
\hline & & 0,17272 & $\mathrm{~mm}$ & Total Composite Tolerance \\
\hline & & 0,152 & $\mathrm{~mm}$ & Tooth Thickness Tolerance \\
\hline & & & Imm & Hob Protuberance \\
\hline & & 36,15 & deg & Roll Angle at Major Diameter \\
\hline & & & deg & Roll Angle at TIF Diameter \\
\hline
\end{tabular}

Table 3. Geometric parameters of the sun gear

\section{TOOTH CONTACT ANALYSIS}

The aim of the TCA is to determine and analyse the mechanical parameters into the tooth connection zone by different loads [3, 4]. In our establishment, the sun gear is the pinion that is why it was loaded by different moments. The gear materials are steel $(\mathrm{E}=210 \mathrm{GPa}$, $\nu=0.3$, isotropic elasticity).

Coordinate systems are defined into the rotation axes 
of the gears and the contact zones between the teeth.

The mesh method is tetrahedrons. Body of influence sizing type is defined into the contact zone to enhance the accuracy of the calculation process. The element size is $0.4 \mathrm{~mm}$ into the contact zone.

\subsection{TCA between the sun gear and the planet pinion}

The sun gear is loaded by different moments ( 40 $80 \mathrm{Nm}$, step: $10 \mathrm{Nm}$ ). The effect of the load moment is analyzed on the tooth surface of the planet pinion. The mesh distribution can be seen on Figure 4.

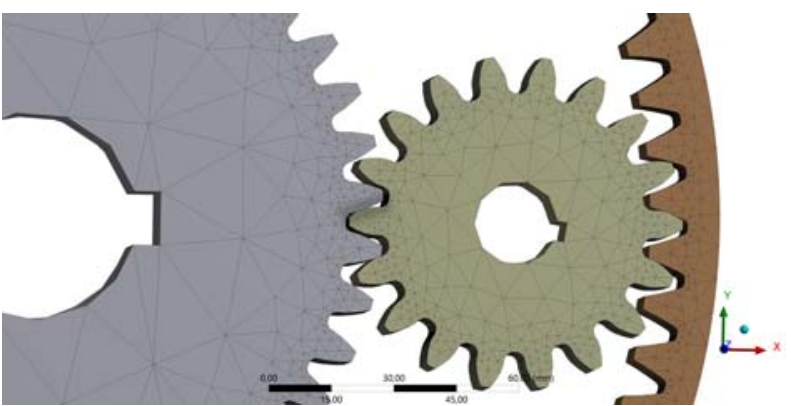

Fig. 4. The mesh for connection analysis between the sun gear and the planet pinion

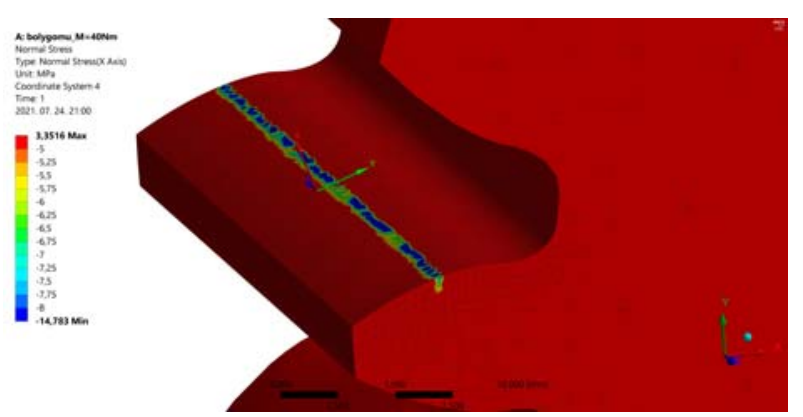

a) $\mathrm{M}=40 \mathrm{Nm}$

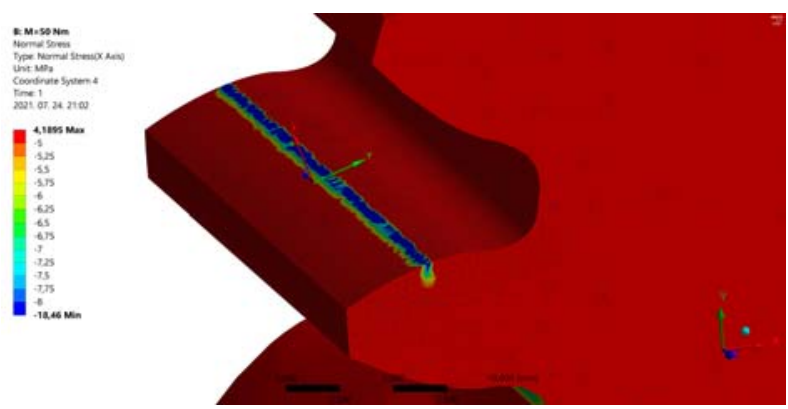

b) $\mathrm{M}=50 \mathrm{Nm}$

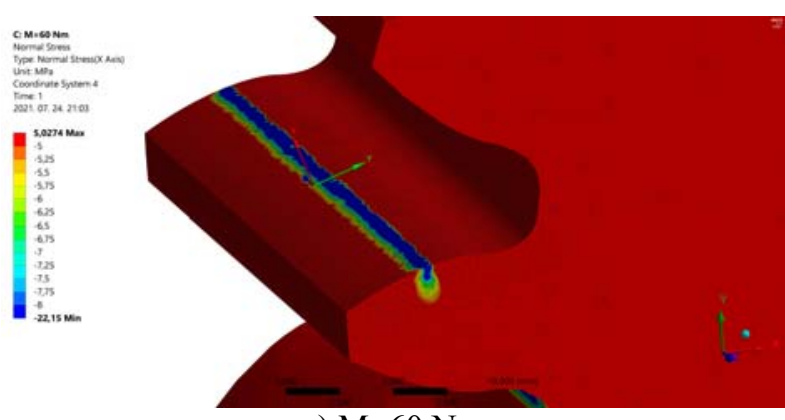

c) $\mathrm{M}=60 \mathrm{Nm}$

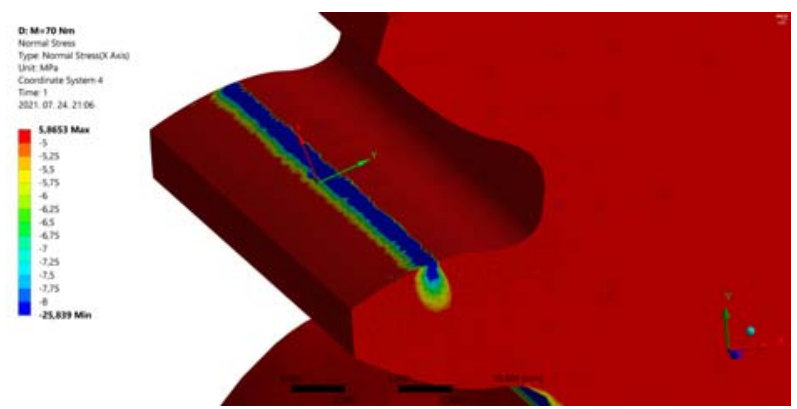

d) $\mathrm{M}=70 \mathrm{Nm}$
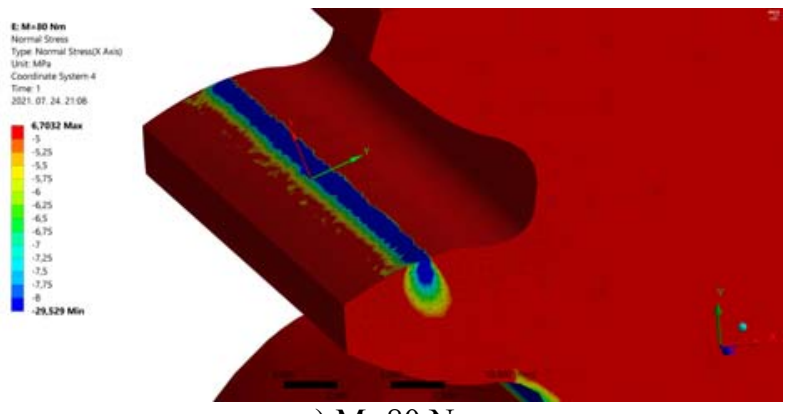

e) $\mathrm{M}=80 \mathrm{Nm}$

Fig. 5. The distribution of the normal stress on the surface of the planet pinion

The results of the normal stress on the tooth surfaces of the planet pinions can be seen on Figure 5 .

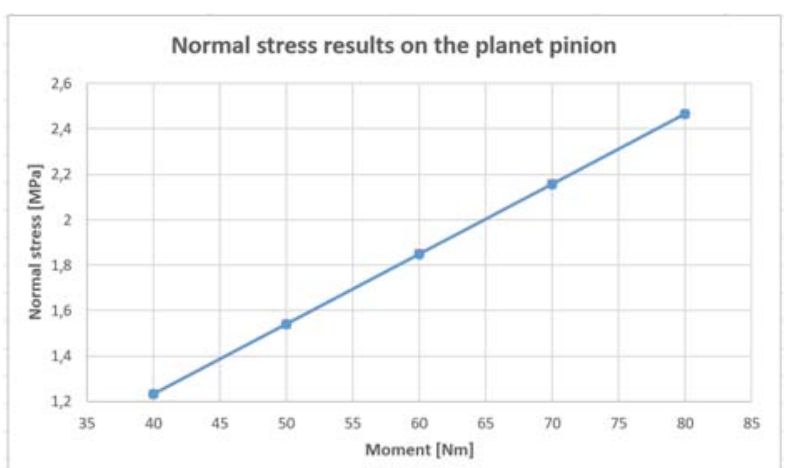

Fig. 6. The results of the normal stress in the funtion of the moment on the surface of the planet pinion

The results of the average normal stresses in the function of the moment can be seen on Figure 6. The more the load moment, the more the normal stress on the tooth surface of the planet pinion.

The results of the normal deformations into the ' $x$ " direction on the tooth surfaces of the planet pinion can be seen on Figure 7.

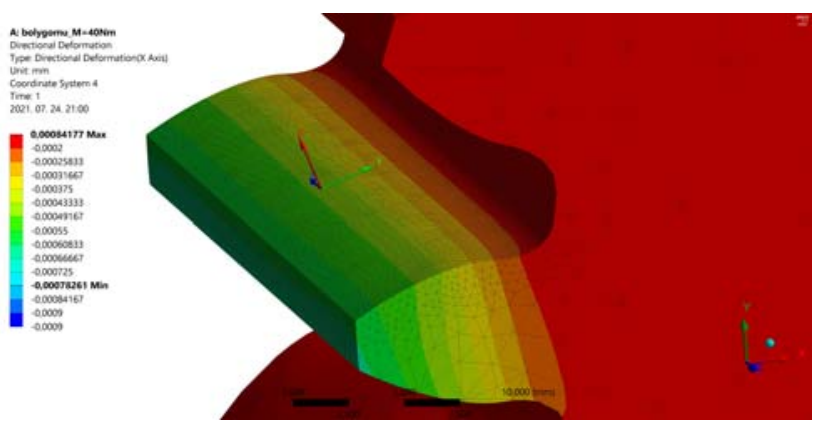

a) $\mathrm{M}=40 \mathrm{Nm}$ 


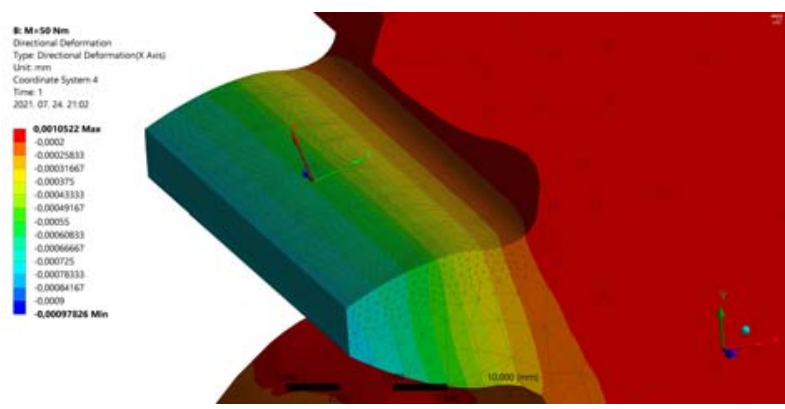

b) $\mathrm{M}=50 \mathrm{Nm}$

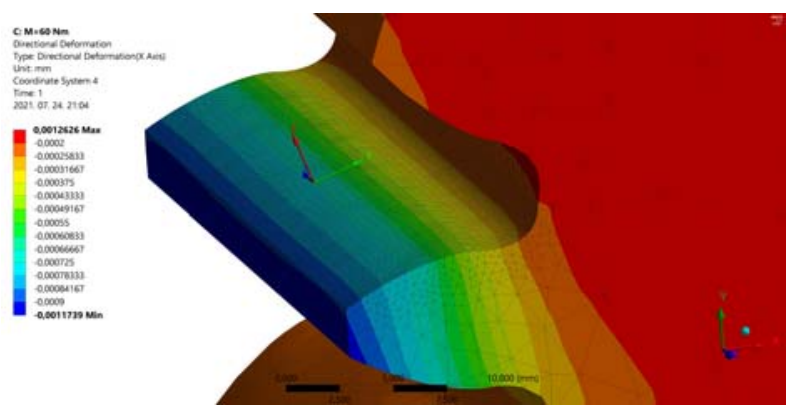

c) $\mathrm{M}=60 \mathrm{Nm}$

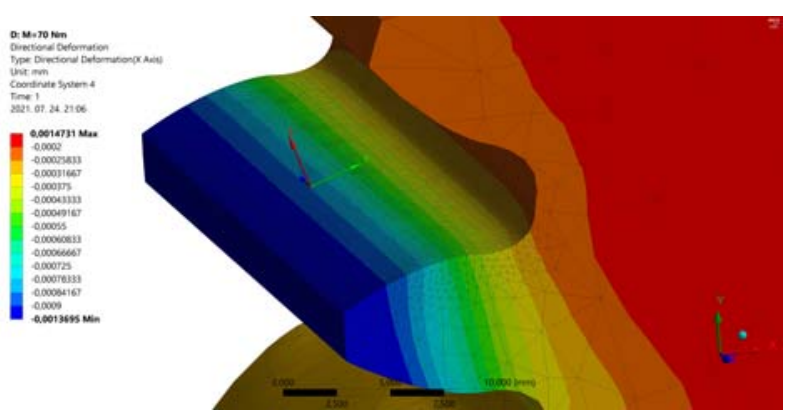

d) $\mathrm{M}=70 \mathrm{Nm}$

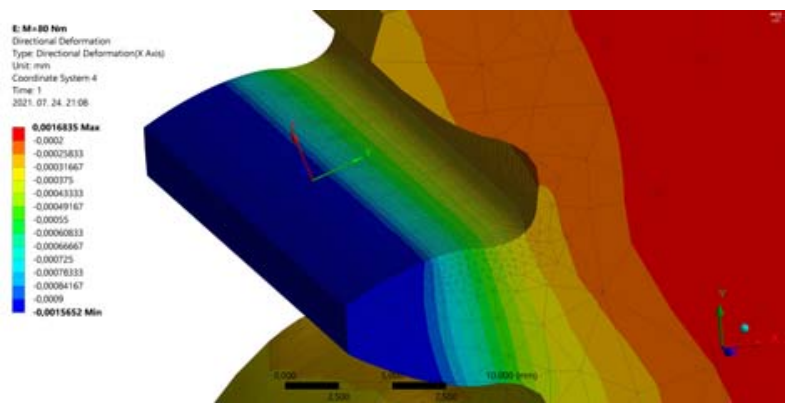

e) $\mathrm{M}=80 \mathrm{Nm}$

Fig. 7. The distribution of the normal deformation on the surface of the planet pinion

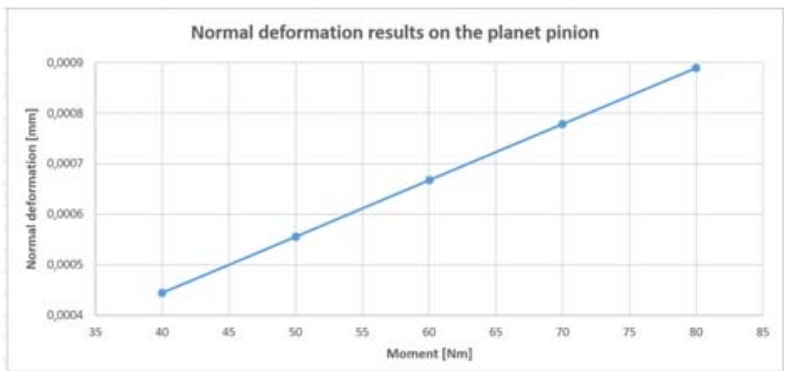

Fig. 8. The results of the normal deformation in the funtion of the moment on the surface of the planet pinion
The results of the average normal deformations in the function of the moment can be seen on Figure 8 . The more the load moment, the more the normal deformation on the tooth surface of the planet pinion.

\subsection{TCA between the planet pinion and the internal gear}

Considering the gear ratio between the sun gear and the planet pinions, the moments have to be recalculated for the planet pinions since these gears are connected with the internal gear. The calculated moments can be seen on Table 4.

\begin{tabular}{|c|c|}
\hline Sun gear & Planet pinions \\
\hline $50 \mathrm{Nm}$ & $18 \mathrm{Nm}$ \\
\hline $60 \mathrm{Nm}$ & $22.5 \mathrm{Nm}$ \\
\hline $70 \mathrm{Nm}$ & $27 \mathrm{Nm}$ \\
\hline $80 \mathrm{Nm}$ & $31.5 \mathrm{Nm}$ \\
\hline $90 \mathrm{Nm}$ & $36 \mathrm{Nm}$ \\
\hline
\end{tabular}

Table 4. The moments on the sun gear and the planet pinions accordingly the gear ratio

The effect of the load moment is analysed on the surface of the internal gear. The meshing strategy is similar than the previous case (Figure 9).
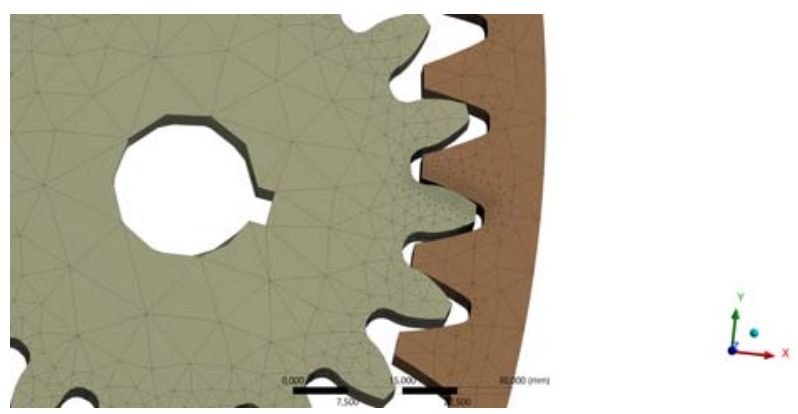

Fig. 9. The mesh for connection analysis between the planet pinion and the internal gear

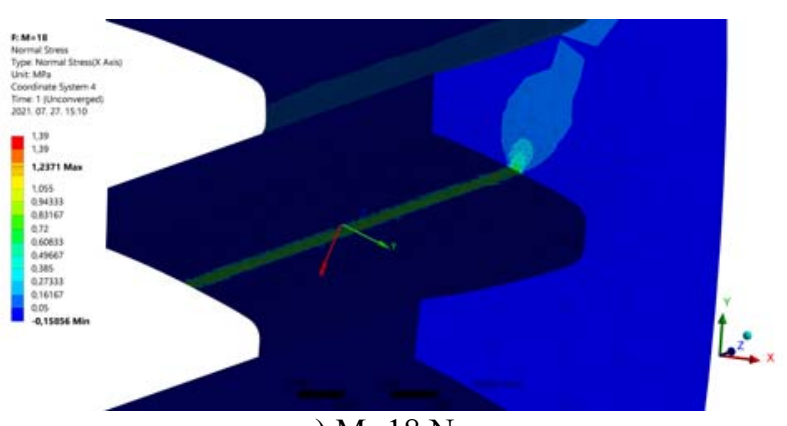

a) $\mathrm{M}=18 \mathrm{Nm}$

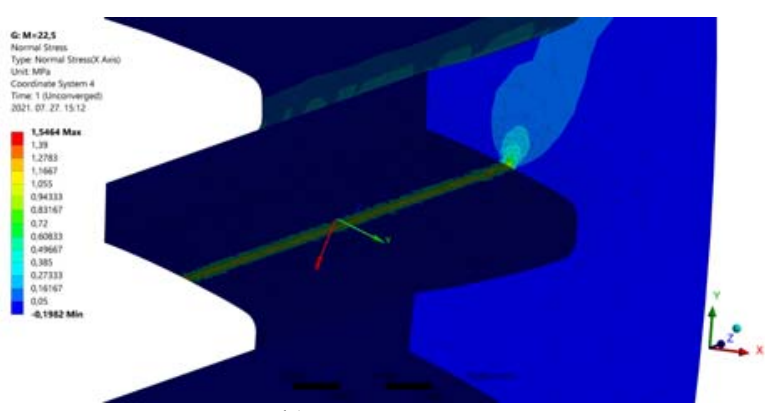

b) $\mathrm{M}=22.5 \mathrm{Nm}$ 


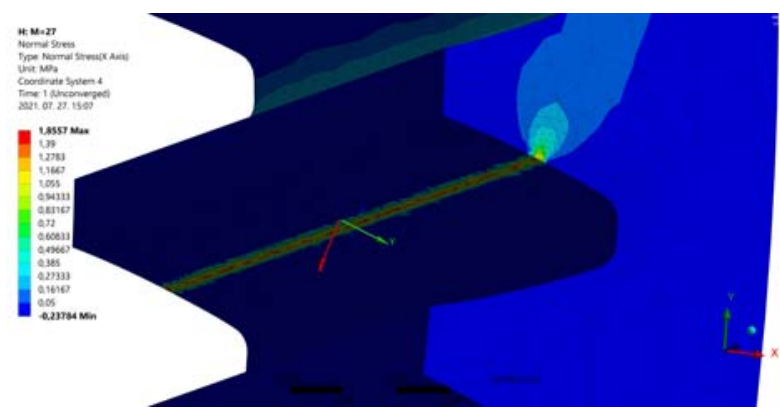

c) $\mathrm{M}=27 \mathrm{Nm}$

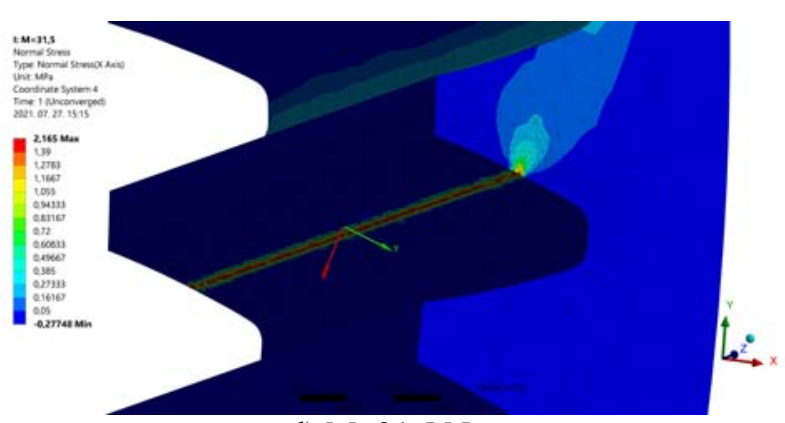

d) $\mathrm{M}=31.5 \mathrm{Nm}$

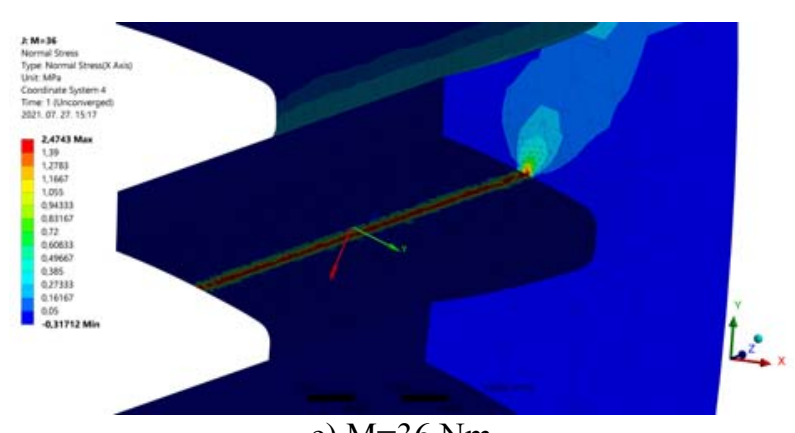

e) $\mathrm{M}=36 \mathrm{Nm}$

Fig. 10. The distribution of the normal stress on the surface of the internal gear

The results of the normal stress on the tooth surfaces of the internal gear can be seen on Figure 10.

The results of the average normal stresses on the tooth surface of the internal gear in the function of the moment can be seen on Figure 11. We got lower stress values since the load moments were lower due to the gear ratio. It is also true the stress is higher if we increase the moment.

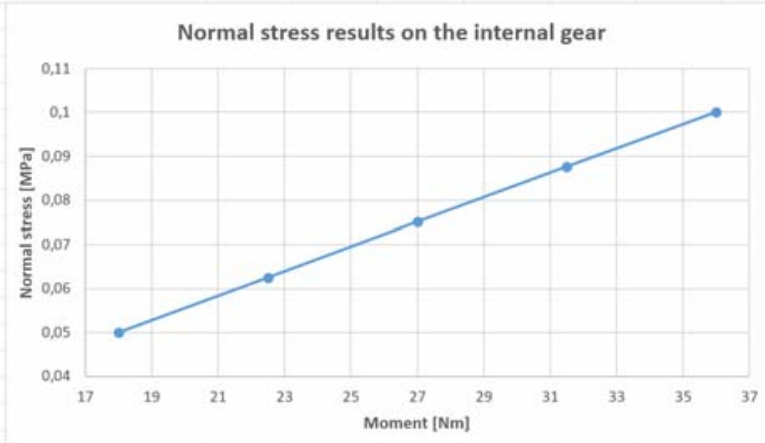

Fig. 11. The results of the normal stress in the funtion of the moment on the surface of the planet pinion

The results of the normal deformations (' $x$ ' directional) on the tooth surfaces of the internal gear can be seen on Figure 12.

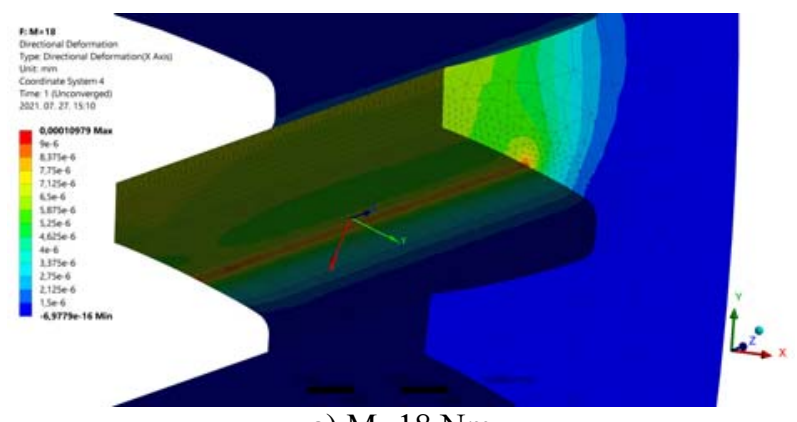

a) $\mathrm{M}=18 \mathrm{Nm}$

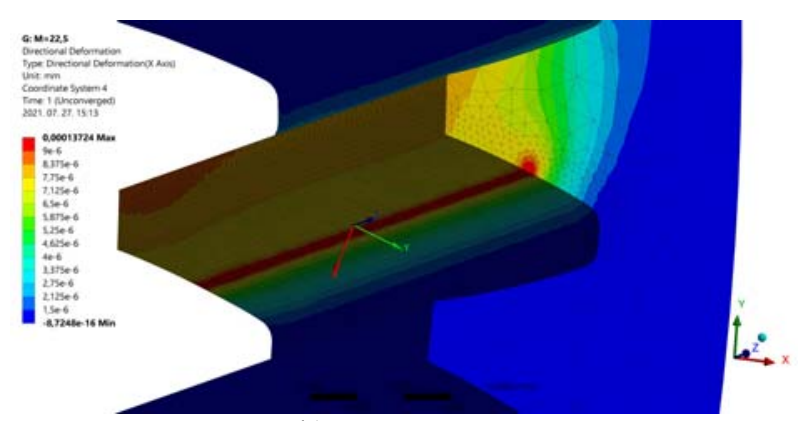

b) $\mathrm{M}=22.5 \mathrm{Nm}$

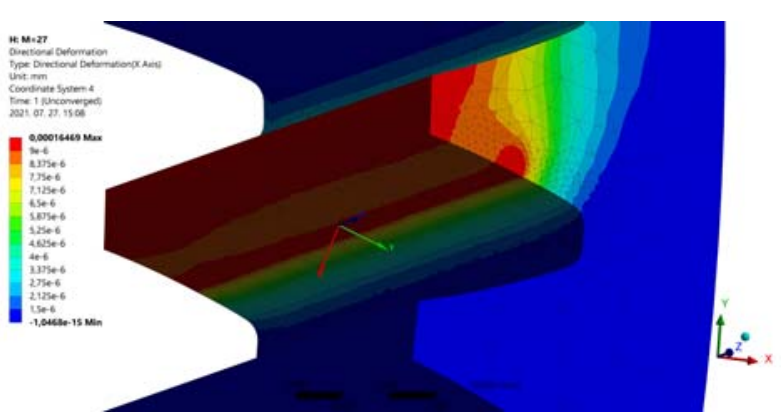

c) $\mathrm{M}=27 \mathrm{~N}$

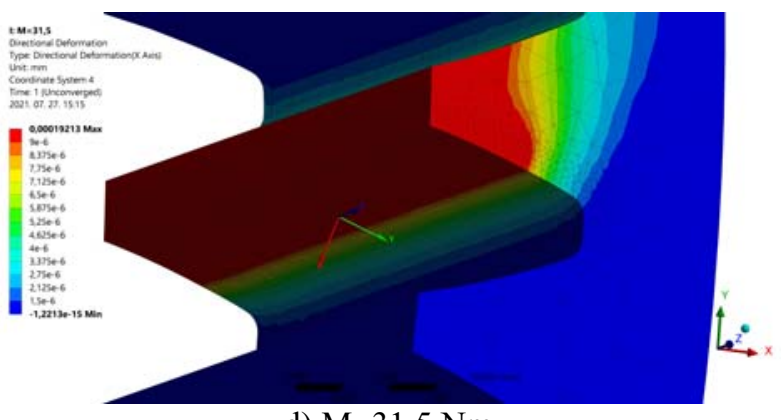

d) $\mathrm{M}=31.5 \mathrm{Nm}$

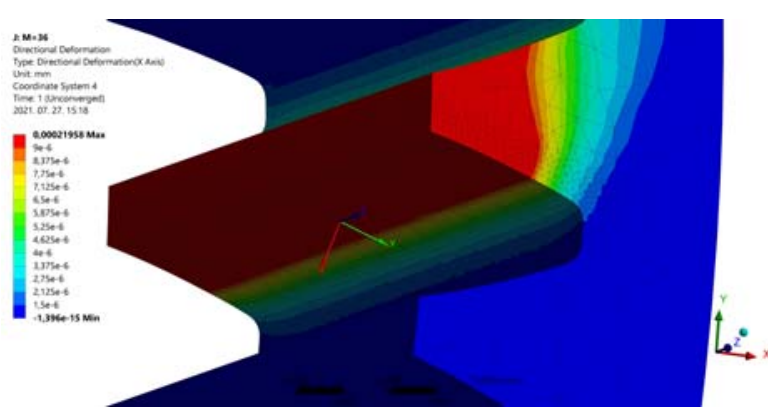

e) $\mathrm{M}=36 \mathrm{Nm}$

Fig. 12. The distribution of the normal deformation on the surface of the planet pinion 
The results of the average normal deformations in the function of the moment can be seen on Figure 12 . We got much lower results than in case of the previous analysis. The reason is the gear ratio, the lower moment and the mass. It is also true that increasing the load moment on the planet pinion the normal deformation is also increasing on the tooth surface of the internal gear.

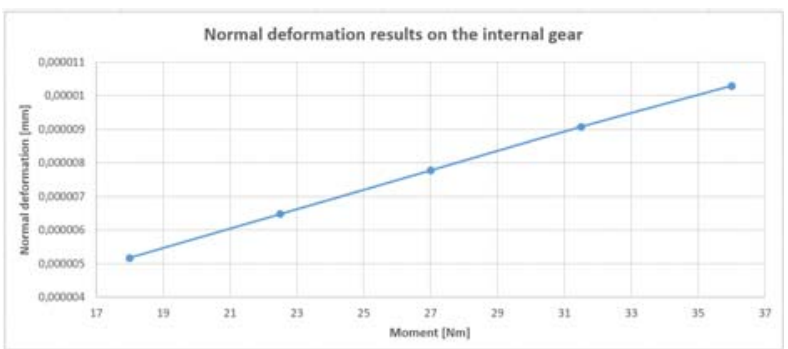

Fig. 13. The results of the normal deformation in the funtion of the moment on the surface of the internal gear

\section{CONCLUSION}

The vehicle industry is a big filed in the countries that contains two huge fields: vehicle design and vehicle manufacturing. There are more and more vehicles on the roads, consequently the development and the research on this field is actual.

In this study, we designed a complex planetary gear box which is usable in the robotic systems for the vehicle manufacturing.

The geometric parameters was calculated by the help with the GearTeq software. After that, the results could be imported into the SolidWorks three dimensional designer software where the assembly and the motion analysis could be done.

The aim of the TCA is to analyze the mechanical parameters into the tooth connection zone of the gear pairs by different loads. In our case, the load was the moment on the pinions. Firstly, we analyzed the TCA parameters between the sun gear and the planet pinion. Four planet pinions were used around the perimeter of the sun gear. Secondly, we analyzed the same parameters between the planet pinion and the internal gear. In this case, the moments had to be recalculated accordingly the gear ratio from the sun gear, which is the pinion, to the planet pinions, which are intermediary gears. We made diagrams from the results and evaluated the overall analysis. This analysis process is necessary to control the correctness and the function of such gear systems before the real installation into the machines [8].

\section{REFERENCES}

[1] https://hu.wikipedia.org/wiki/Bolyg\%C3\%B3m\% $\mathrm{C} 5 \% \mathrm{~B} 1$

[2] Bodzás, S., Békési, Zs., Ketész, J., Szorcsik, T.: The CAD modelling possibilities of the GearTeq 2021 software in the mechanical engineering practice, International Journal of Engineering and Management Sciences, Debrecen, 2021, (under review)
[3] Litvin, F. L., Fuentes, A. A.: Gear Geometry and Applied Theory, Cambridge University Press, 2004, ISBN 9780521815178

[4] Litvin, F. L., Fuentes. A. A., Vecchiato, D., Gonzalez-Perez, I.: New Design and Improvement of Planetary Gear Trains, NASA Center for Aerospace Information, 2004, p. 32, https://ntrs.nasa.gov/api/citations/20040086788/do wnloads/20040086788.pdf

[5] Goldfarb, V., Trubachev, E., Barmina, N.: Advanced Gear Engineering, Springer, 2018, p. 197., ISBN 978-3-319-60398-8

[6] Rackov, M., Knežević, I., Čavić, M., Penčić, M., Čavić, D., Kuzmanović, S. Design Solutions Overview of Universal Motor Gear Drives with Helical Gears, 10th International Symposium on Graphic Engineering and Design (GRID 2020), Novi Sad, Serbia, 12-14 November 2020, pp. 597608, https://doi.org/10.24867/GRID-2020-p68

[7] Radzevich, S. P.: Dudley's Handbook of Practical Gear Design and Manufacture, Third edition, CRC Press, 2016, p. 656, ISBN 9781498753104

[8] Golebski, R., Boral, P.: Study of Machining of Gears with Regular and Modified Outline Using CNC Machine Tools, Materials 14 (11): 2913, 2021, DOI:10.3390/ma14112913

[9] Terplán, Z., Apró, F., Antal, M., Döbröczöni, Á.: Fogaskerék-bolygómúvek, Müszaki könyvkiadó, Budapest, 1979, p. 258

\section{ACKNOWLEDGEMENT}

Project no. TKP2020-NKA-04 has been implemented with the support provided from the National Research, Development and Innovation Fund of Hungary, financed under the 2020-4.1.1-TKP2020 funding scheme.

\section{Authors:}

Sándor Bodzás, Ph.D., Deputy head of department, associate professor, University of Debrecen, Department of Mechanical Engineering, Hungary, email: bodzassandor@eng.unideb.hu

Zsolt Békési, assistant lecturer, University of Debrecen, Department of Air- and Load Vehicle, e-mail: zsolt.bekesi@eng.unideb.hu

József Kertész, technical assistant, University of Debrecen, Department of Air- and Load Vehicle, email: kertesz.jozsef@eng.unideb.hu

Tamás Szorcsik, mechanical engineer, TRIGON Electronica Ltd., Salgótarján, Hungary, e-mail: tamas.szorcsik@trigone.hu 